Çukurova Üniversitesi Mühendislik Mimarlık Fakültesi Dergisi, 34(2), ss. 73-85, Haziran 2019

Çukurova University Journal of the Faculty of Engineering and Architecture, 34(2), pp. 73-85, June 2019

\title{
Atık Pil Tozu Liç Kalıntısındaki Manganın Çözünürlüğü için Optimum Koşulların Yanıt Yüzey Yöntemiyle Belirlenmesi
}

\author{
Gülistan Deniz TURHAN ÖZDEMİR ${ }^{1}$, Nizamettin DEMİRKIRAN*1 \\ ${ }^{1}$ İnönü Üniversitesi, Mühendislik Fakültesi, Kimya Mühendisliği Bölümü, Malatya.
}

Geliş tarihi: 04.01.2019 Kabul tarihi: 28.06.2019

Öz

Bu çalışmada, bitmiş çinko karbon ve alkali pillerden hazırlanan atık pil tozundaki çinko oksidin nitrik asit çözeltisinde çözündürülerek giderilmesinden sonra geriye kalan liç kalıntısındaki manganın çözünürlüğü için optimum parametre değerleri belirlenmiş̧ir. Sülfürik asit derişimi, reaksiyon sicaklı̆ğ ve reaksiyon süresi bağımsız değişkenler olarak seçilmiş ve çözünürlüğe etki eden parametre değerlerini optimize etmek için yanıt yüzey yöntemi (RSM) kullanılmıştır. Mangan çözünürlüğünü artırmak için indirgen madde olarak melas kullanılmıştır. Proses parametrelerinin etkilerini görebilmek için deneysel bulgulara çoklu regresyon analizi yapılmış ve modifiye bir denklem elde edilmiştir. Deneyler sonucunda sülfürik asit derişimi, reaksiyon sıcaklığı ve reaksiyon sürenin artmasıyla liç veriminin arttığı belirlenmiștir. Reaksiyon sıcaklığı ve reaksiyon sürenin çözünme üzerinde daha etkili parametreler olduğu gözlenmiştir. Maksimum liç verimine ulaşmak için optimum deney koşulları 2,07 mol/L, $68,8{ }^{\circ} \mathrm{C}$ ve $120 \mathrm{dk}$ olarak bulunmuştur. Optimum koşullar altında mangan çözünürlüğünün \%93 olduğu belirlenmiştir.

Anahtar Kelimeler: Atık pil, Mangan, Liç, Optimizasyon, Yanıt yüzey yöntemi

\section{Determination of Optimal Conditions for Dissolution of Manganese in the Leach Residue of Waste Battery Powder by Response Surface Method}

\begin{abstract}
In this work, the optimal parameter values for the dissolution of manganese in the leach residue were determined after zinc oxide in the waste battery powder prepared from spent zinc carbon and alkaline batteries was removed by dissolving in nitric acid solution. The concentration of sulfuric acid, reaction temperature and reaction time were selected as independent variables, and response surface method (RSM) was used to optimize the parameter values that have an effect on the dissolution. Molasses was utilized as reducing agent to increase the dissolution of manganese. To see the interactive effects of process variables, the multiple regression analysis to the experimental findings was performed, and a modified equation was obtained. At the end of the experiments, it was determined that the leaching efficiency increased with an increase in the concentration of sulfuric acid, reaction temperature and reaction time. It was observed that the reaction temperature and reaction time were more effective parameters on the dissolution. To reach the maximum leaching efficiency, the optimum experimental conditions were found to be $2.07 \mathrm{~mol} / \mathrm{L}, 68.8^{\circ} \mathrm{C}$ and $120 \mathrm{~min}$. It was determined that $93 \%$ of manganese in the solid residue was dissolved under optimal conditions.
\end{abstract}

Keywords: Waste battery, Manganese, Leaching, Optimization, Response surface methodology

*Sorumlu yazar (Corresponding author): Nizamettin DEMIRKIRAN, nizamettin.demirkiran@inonu.edu.tr 


\section{GíRiş}

Sulu çözeltilerde gerçekleşen kimyasal reaksiyonlar yoluyla metal, metal tuzları ve bileşiklerinin üretimini içeren hidrometalurji, esas olarak düşük tenörlü oksitli cevherlerden metal üretimine uygulanmakla birlikte, günümüzde çeşitli atıklardan metal kazanma ve üretiminde de kullanılmaktadır. Hidrometalurjide temel basamak, istenen metali içeren bir katının uygun bir çözücü ile reaksiyona girmesini ve bu metalin katı fazdan sıvı faza kütle transferini içeren liç işlemidir. Liç işleminde kullanılan çözücünün türü, çözücünün derişimi, reaksiyon sıcaklığı, katı/sıvı oranı, karıştırma hızı ve tane boyutu gibi çeşitli parametreler liç verimini etkilediğinden metal kazanma verimi üzerinde de doğrudan bir etkiye sahiptir [1,2].

Endüstrinin en çok faydalandığ 1 demir dışı metallerden birisi olan mangan, başlıca demir çelik sektöründe, ferro manganez üretiminde, alüminyum alaşımlarında, gübre, cam, boya, kuru pil ve seramik üretimi ile petrokimya ve elektronik sektöründe kullanım alanı bulmaktadır. Mangan için temel hammadde kaynağı piroluzit $\left(\mathrm{MnO}_{2}\right)$ gibi doğal cevherler olmakla beraber son yıllarda ekonomik ve çevresel sebeplerden ötürü çeşitli atıklardan da manganın geri kazanılmasına yönelik çalışmalar yürütülmektedir [3,4]. Mangan içeren katı atıklar arasında çinko karbon ve alkali çinko mangan dioksit piller önemli bir yere sahiptir. Bu tip pillerin dünya genelinde yılda yaklaşık 90 milyar adet civarında tüketildiği ifade edilmektedir. Çinko karbon ve alkali çinko mangan dioksit pillerin üretiminde kullanılan metal miktarları kaynaklarda farklı değerlerde verilmiş olmakla birlikte, bir çinko karbon pilin toplam kütlesinin yaklaşık \%26'sını ve bir alkali çinko mangan dioksit pilin ise toplam kütlesinin yaklaşık \%35'ini mangan oluşturmaktadır $[1,5,6]$. Dolayısıyla sözü edilen pil türlerinden oluşacak atıklar da önemli miktarda mangan içerirler ve mangan üretimi için ikincil hammadde kaynağ 1 olarak değerlendirilebilirler. Aynı zamanda bu atıklar çinko için de bir kaynak olarak kullanılabilir. Böylece çevreye bırakılan atık pil miktarında bir azalma sağlanmış olacağı gibi, atıkların ekonomiye kazandırılması ve bir dereceye kadar metallerin doğal kaynaklarının korunması da sağlanabilir. $\mathrm{Bu}$ gibi önemlerinden dolayı son yıllarda hidrometalurjik yöntemlerin uygulanmasıyla atık pillerden mangan ve çinko kazanmaya yönelik yapılan araştırmaların sayısında artış olduğu görülmektedir.

Hidrometalurjik yöntemlerin uygulanmasıyla bitmiş alkali çinko mangan dioksit ve çinko karbon pillerden metal kazanma ile ilgili olarak yapılan çalışmalarda, asidik ve bazik özelliğe sahip farklı çözücüler liç reaktifi olarak kullanılmıştır [7-11]. Yapılan çalışmalarda pil tozlarındaki metal değerlerin çözünmesi üzerine reaksiyon sıcaklığı, çözücü derişimi, katı/sıvı oranı, reaksiyon süresi, tane boyutu ve karıştırma hızı gibi parametrelerin etkileri araştırılmıştır [12-17].

Bir katı maddeden istenen bir metalin liç işlemi ile kazanılmasına yönelik çalışmalarda, liç verimi üzerine bir parametrenin etkisi incelenirken genellikle diğer parametreler belli bir değerde sabit tutulur. Her bir deney parametresinin etkisinin incelenmesinde aynı yola başvurulduğu için birçok deney yapılması gerekmektedir ve aynı zamanda parametreler arasındaki karşılıklı ilişki de gözlenememektedir. Böylece yapılacak deney sayısını azaltmak, liç verimi üzerine etki eden parametrelerin etkilerini belirlemek amacıyla çeşitli deneysel tasarım yöntemlerine başvurulabilir. Literatürde son yıllarda Taguchi, Box-Behnken ve merkezi karma tasarım (CCD) gibi çeşitli deneysel tasarım yöntemlerinin kullanıldığı liç çalışmalarının gerçekleştirildiği görülmektedir [18-21].

Hidrometalurjik çalışmalarda deneysel tasarım yöntemlerinin kullanılmasının en önemli avantajları deneysel çalışmaları en aza indirmek, önemli parametreleri belirlerken önemsiz parametreleri elemek, hataların etkisini azaltmak, parametreler arasındaki etkileşimleri belirlemek, parametreler arasındaki matematiksel ilişkiyi ortaya çıkarmak ve sonuçların üç boyutlu grafiklerle gösterimini sağlamak olduğu söylenebilir [21]. Yanıt yüzey yöntemi (Response Surface Method, RSM), düzeyleri önceden belirlenmiş birden fazla bağımsız değişkenin bağımlı değişken (yanıt) üzerindeki etkilerini 
ortaya koymak için sıklıkla başvurulan deneysel tasarım yöntemlerinden birisidir. En yaygın kullanılan yanıt yüzey yöntemlerinden birisi merkezi karma tasarım yöntemidir. Bu yöntemde iki düzeyli faktöriyel nokta, eksenel nokta ve merkezi nokta olmak üzere üç tür tasarım noktası bulunmaktadır. İki düzeyli faktöriyel nokta -1 ve +1 düzeylerinin tüm olası kombinasyonlarını içerir. Eksenel noktalar $\pm \alpha$ ve merkezi nokta (0) değerlerini alarak oluşturulan noktalardır [22].

Atık pillerden metal kazanımında yanıt yüzey yönteminin uygulandığı çeşitli çalışmalar literatürde mevcuttur. Atık nikel kadmiyum ve nikel metal hidrit pillerden biyoliç yönteminin uygulanmasıyla nikel, kadmiyum ve kobalt gibi ağır metallerin kazanımının istatistiksel değerlendirilmesi ve optimizasyonunun incelendiği bir çalışmada, yanıt yüzey yöntemlerinden birisi olan Box-Behnken yöntemi kullanılmıştır. Bu çalışmada nikel, kadmiyum ve kobalt kazanımı üzerine etkili olan bağımsız değişkenler olarak $\mathrm{pH}$, $\mathrm{Fe}^{3+}$ derişimi ve tane boyutu seçilmiş ve optimum deneysel koşulların belirlenmesine yönelik çalışmalar yapılmıştır. Deneyler neticesinde $\mathrm{pH}$, $\mathrm{Fe}^{3+}$ derişimi ve tane boyutunun sırasıyla 1,0 , $9,7 \mathrm{~g} / \mathrm{mL}$ ve $62,0 \mu \mathrm{m}$ olduğu deney koşulları optimum koşullar olarak belirlenmiştir. $\mathrm{Bu}$ değerler kullanılarak yapılan deneyler sonucunda nikel, kadmiyum ve kobalt için sirasıyla \% 85,6, $\%$ 66,1 ve \% 90,6 bir liç verimine ulaşılmıştır [23].

Alkali çinko mangan dioksit, çinko karbon, nikel kadmiyum, nikel metal hidrit ve lityum atık pillerinin karışımından metal değerlerin kazanılması amacıyla yapılan bir çalışmada, optimum koşulları belirlenmek için üç seviyeli tam faktöriyel tasarım yöntemi uygulanmıştır. Çalışmada çözücü ajan olarak sülfürik asit ve indirgen madde olarak sodyum metabisülfit kullanılmıştır. Sülfürik asit derişimi, katı/sıvı oranı, sodyum metabisülfit miktarı ve reaksiyon süresinin bağımsız değişkenler olarak alındığı çalışmada, atık pil tozu karışımındaki kadmiyum, kobalt, mangan, nikel ve çinkonun yüzde çözünürlük değerleri belirlenmiştir. Deneyler sonucunda sülfürik asit derişimi, katı/sıv1 oranı, sodyum metabisülfit miktarı ve reaksiyon süresi için optimum değerler sırasıyla 1,34 mol/L,
$\% 10,9$ (w/v), 0,45 g ve 45 dakika olarak belirlenmiştir. $\mathrm{Bu}$ optimum koşullarda çinko için \%99, kobalt için \%96, mangan için \%94, kadmiyum için \%81 ve nikel için \%68’lik bir liç verimi elde edilmiştir [24].

Yanıt yüzey yöntemlerinden birisi olan merkezi karma tasarımın uygulandığı başka bir çalışmada ise herhangi bir indirgeyici madde içermeyen sülfürik asit çözeltileri kullanılarak bitmiş çinko karbon pillerden seçimli liç yoluyla çinko çözünürlüğünü maksimum, mangan çözünürlüğünü ise minimum düzeyde tutacak deney şartlarının belirlenmesi araştırılmıştır. Yapılan deneyler neticesinde sülfürik asit derişimi, reaksiyon sıcaklığı ve karıştırma hızının sırasıyla $1 \mathrm{~mol} / \mathrm{L}, 70{ }^{\circ} \mathrm{C}$ ve $300 \mathrm{rpm}$ olduğu koşullarda pil tozundaki çinkonun çözünmesinin maksimum olduğu (\%92) buna karşılık mangan çözünmesinin ise minimum düzeyde (\%15) kaldığı tespit edilmiştir [25].

İndirgen ajan olarak glikoz varlığından sülfürik asit çözeltilerinin çözücü olarak kullanıldığı çalışmada, atık çinko karbon pillerden mangan ve çinko kazanımı iki seviyeli tam faktöriyel deney tasarım yöntemiyle incelenmiştir. Bağımsız değişkenler olarak sülfürik asit derişimi, glikoz miktarı, çözelti hacmi ve reaksiyon sıcaklığının seçildiği çalışmada, çinko ve manganın çözünmesi için bağımsız değişkenler ve yanıtlar arasındaki ilişkiyi gösteren model denklemler önerilmiştir. Çözelti hacminin $250 \mathrm{~mL}$, sülfürik asit derişiminin $2 \mathrm{~mol} / \mathrm{L}$, glikoz miktarının 0,5 g ve reaksiyon sıcaklığının $100{ }^{\circ} \mathrm{C}$ olduğu deney koşullarında, katı pil tozunda bulunan her iki metal türünde yaklaşık \%100 oranında çözeltiye geçtiği belirlenmiştir [6].

Bağımsız değişkenlerin etkilerini belirleyebilmek ve parametre etkilerini optimize edebilmek amacıyla, çeşitli liç çalışmalarının yanı sıra fotokataliz [26], gida [27] ve adsorpsiyon [28] gibi birçok araştırma alanında da yanıt yüzey yönteminin uygulandığı deneysel çalışmalar yürütülmüştür.

Atık alkali çinko mangan dioksit ve çinko mangan pil tozlarındaki mangan oksitler indirgen bir 
madde içermeyen asidik bir çözeltide zor çözünürken, çinko oksit kısa sürelerde kolaylıkla çözünebilmektedir. Atık pil tozundaki metal değerler hidrometalurjik yöntemle kazanılmak istendiğinde, pil tozu bir liç işlemine maruz bırakılır. Kullanılan çözücüye bağlı olarak liç sonunda her iki metal türün iyonlarına ilave olarak pilin yapısındaki diğer metal türlerde çözünerek çözelti ortamına geçebilir. Böylece birden fazla metal türü içeren bir çözelti elde edilmiş olur. İstenen metal iyonunu yüksek oranda içeren bir çözelti elde etmek için ya istenen türü çözeltiden kazanmak ya da istenmeyenleri uzaklaştırmak amacıyla bir takım ayırma ve saflaştırma proseslerinin uygulanması gerekir. $\mathrm{Bu}$ işlemlerin uygulanması yerine seçimli bir liç işleminin uygulanmasıyla gerekli olan ayırma ve saflaştırma işlemlerinin sayısı azaltılabilir veya bu işlemleri uygulamaya gerek kalmayabilir. Seçimli liç işlemi ile katı maddedeki metal türlerden biri kullanılan çözücüye bağlı olarak çözelti ortamına alınırken diğer metal türler çözünmeden katı bünyesinde kalır. Dolayısıyla liç işlemi sonunda ilgili metal bakımından zengin bir çözelti elde edilmiş olur.

Bu çalışmada atık alkali çinko mangan dioksit ve çinko karbon pillerden elde edilen pil tozundaki çinko oksidin nitrik asit çözeltisinde çözündürülerek uzaklaştırılmasından sonra kalan katı kalıntıdaki manganın, indirgen madde olarak kullanılan melas varlığında sülfürik asit çözeltilerinde liç verimine etki eden parametrelerin optimum değerlerinin belirlenmesi amaçlanmıştır. Merkezi karma tasarım yöntemlerinden birisi olan yüzey merkezli kompozit tasarım (CCF) yöntemi kullanılmıştır. İstatistiksel analiz yapılarak mangan çözünürlüğü için optimum koşullar belirlenmiştir.

\section{MATERYAL VE METOT}

\subsection{Materyal}

Malatya ilinde toplanan bitmiş alkali ve çinko karbon piller manuel olarak parçalanıp metal, kâğıt ve plastik kisımlar ayrıldıktan sonra her iki pil türündeki tozlar karıştırılmış ve deneylerde kullanılacak olan atık pil tozu hazırlanmıştır. Pil tozu oda sicaklığında kurutulduktan sonra öğütülmüş ve farklı boyutlara sahip örnekler elde etmek için elenmiştir. Deneylerde $-50+70$ mesh boyutuna sahip pil tozu örnekleri kullanılmıştır. Pil tozunun kimyasal analizi Spectro Xcpus XRF spektrometre ile yapılmış ve ortalama olarak \%50,3 $\mathrm{MnO}$, \%24,9 $\mathrm{ZnO}$, \%3,8 $\mathrm{K}_{2} \mathrm{O}$ ve \%19 C içerdiği belirlenmiştir. Örneğin nem içeriği bir etüvde $105{ }^{\circ} \mathrm{C}$ 'de kurutma sonucunda \%2 olarak tespit edilmiştir. Çinko ve mangan iyonlarını birlikte içeren bir liç çözelti elde etmemek amacıyla, optimizasyon deneylerinden önce atık pil tozu $0,5 \mathrm{~mol} / \mathrm{L}$ nitrik asit çözeltisiyle 10 dakika süreyle muamele edilerek çinko oksidin çözünmesi sağlanmıştır. Bu işlem sonunda pil tozundaki çinko oksidin tamamen çözündüğü, mangan oksidin ise \%7 kadarının çözeltiye geçtiği tespit edilmiştir. Aynı zamanda pil tozundaki $\mathrm{K}_{2} \mathrm{O}$ 'nun da giderildiği belirlenmiştir. Nitrik asitte çözme işleminden sonra mangan oksitler ve karbon içeren katı kalıntı çözeltiden ayrılarak oda sıcaklığında kurutulmuş ve optimizasyon deneylerinde kullanılmıștır. Elde edilen kalıntıya ait XRD analizi Rigaku RadB-DMAX II model X-ray difraktometresi ile yapılmıştır. Çinko oksit çözündükten sonra kalıntı pil tozunun XRD grafiği Şekil 1'de verilmiştir. Şekil 1'de $\mathrm{ZnO}$ piki gözlenmemekte ve kalıntının başlıca farklı yükseltgenme basamaklarına sahip mangan oksitler ve karbondan ibaret olduğu anlaşılmaktadır. Kalıntının kimyasal analizi de sözü edilen spektrometre ile yapılmış ve \%66,7 $\mathrm{MnO}$ ve \%31,3 C içerdiği belirlenmiştir. Kalıntının nem içeriği $105{ }^{\circ} \mathrm{C}$ 'de etüvde kurutma sonucunda $\% 2$ olarak belirlenmiştir.

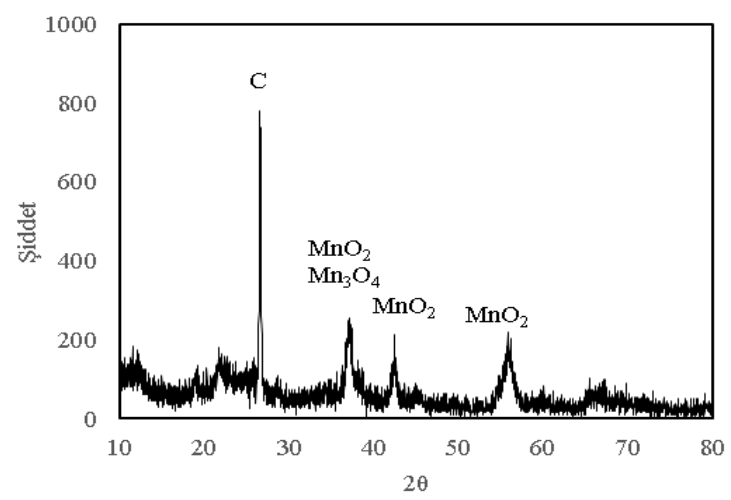

Şekil 1. Çinko oksit çözündükten sonra kalıntı pil tozunun XRD grafiği 


\subsection{Metot}

Mangan liç deneyleri ceketli cam reaktör, sirkülatörlü su banyosu, mekanik karıştırıcı ve geri soğutucudan oluşan bir deney düzeneğinde gerçekleştirilmiştir. Derişimi bilinen $500 \mathrm{~mL}$ sülfürik asit çözeltisi cam reaktöre konulduktan sonra sıcaklık değeri çalışma sıcaklığına getirilmiş ve $8 \mathrm{~g}$ katı örnek reaktöre ilave edilerek $500 \mathrm{rpm}$ karıştırma hızında deneyler yapılmıştır. Mangan çözünürlüğünü arttırmak amacıyla tüm deneylerde 3 g melas kullanılmıştır. Deney süresi sonunda çözeltiden alınan örneklerde katıdan çözünerek çözeltiye geçmiş olan mangan miktarı kompleksometrik titrasyonla belirlenmiştir. Çözünmüş olan mangan miktarı Eşitlik 1'den hesaplanmıştır.

\% Çözünen mangan $=\frac{\mathrm{m}_{0}-\mathrm{m}_{\varsigma}}{\mathrm{m}_{0}} .100$
Eşitlik 1'de $m_{0}$ başlangıçta katıdaki mangan kütlesini (g) ve $\mathrm{m}_{c ̧}$ çözeltideki mangan kütlesini (g) temsil etmektedir. Deneylerde bağımsız değişkenler olarak seçilen sülfürik asit derişimi, reaksiyon sicaklığı ve reaksiyon süresinin yanıt üzerine (\% çözünen mangan, Y) olan etkileri incelenmiştir. Bağımsız değişkenler ve düzeyleri Çizelge 1'de verilmiştir. Regresyon ve varyans analizleri (ANOVA) Design Expert Yazılımı (Version 10.0.6.0) ile yapılmıştır.

Çizelge 1. Deney parametreleri ve değerleri

\begin{tabular}{|l|c|c|c|c|}
\hline \multirow{2}{*}{ Bağımsız Değişken } & \multirow{2}{*}{ Kod } & \multicolumn{3}{|c|}{ Düzey } \\
\cline { 3 - 5 } & & -1 & 0 & 1 \\
\hline Sülfürik asit derişimi, mol/L & $\mathrm{A}$ & 0,5 & 1,5 & 2,5 \\
${\text { Reaksiyon sıcaklı̆̆ } 1,{ }^{\circ} \mathrm{C}}^{\mathrm{C}}$ & $\mathrm{B}$ & 30 & 50 & 70 \\
Reaksiyon süresi, dk & $\mathrm{C}$ & 10 & 65 & 120 \\
\hline
\end{tabular}

Çalışmada izlenen deneysel yöntem Şekil 2'de verilmiştir.

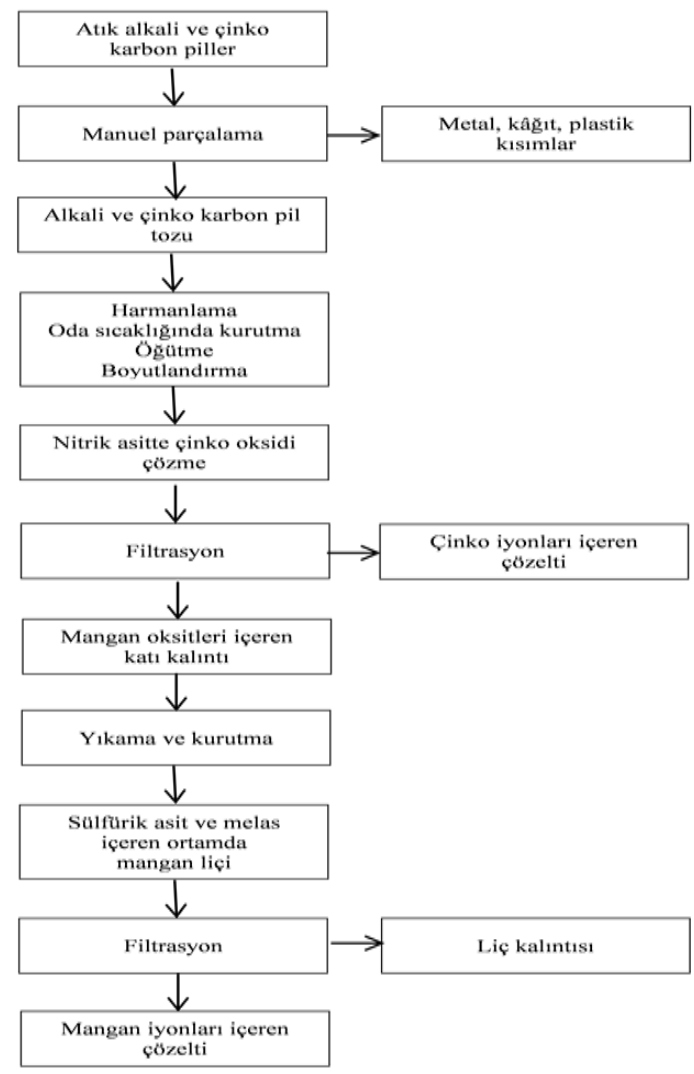

Şekil 2. Çalışmada izlenen deneysel yöntemi temsil eden akış şeması 


\section{BULGULAR VE TARTIŞMA}

Alkali çinko mangan dioksit ve çinko karbon pillerin kullanımı sırasında anot ve katot olarak kullanılan maddeler yükseltgenme ve indirgenme reaksiyonlarına uğrayarak farklı kimyasal türlere dönüşürler. Çinko karbon pillerde anot olarak silindir biçiminde metalik çinko kullanılırken, alkali pillerde bu görevi toz halinde kullanılan metalik çinko görmektedir. Her iki pil türünde de katot olarak mangan (IV) oksit $\left(\mathrm{MnO}_{2}\right)$ kullanılır. Yükseltgenme sonucunda çinko, çinko okside dönüşürken mangan (IV) oksit indirgenir ve farklı yükseltgenme basamaklarına sahip mangan oksitler oluşur. Dolayısıyla bitmiş bir pil tozunda $\mathrm{MnO}_{2}$ 'den başka $\mathrm{Mn}_{2} \mathrm{O}_{3}, \mathrm{Mn}_{3} \mathrm{O}_{4}$ ve $\mathrm{MnO}$ gibi mangan oksitler bulunabilir. Çinko amfoter özelliğe sahip olduğundan pil tozundaki çinko oksit hem asidik çözeltilerde hem de bazik çözeltilerde çözünür. Mangan oksitler ise bazik ortamda çözünmezken kuvvetli asidik çözeltilerde sınırlı miktarda çözünürler. Yukarıda bahsedilen mangan oksit türleri arasında sulu ortamda çözünürlüğü en yüksek olan mangan (II) oksittir (MnO). Bu sebeple 2+ yükseltgenme basamağından daha yüksek yükseltgenme basamağına sahip mangan oksitlerin sulu ortamda çözünürlüğü yüksek olan $\mathrm{Mn}^{2+}$ iyonlarına indirgenmesi ve böylece mangan oksitlerin çözünme verimini arttırmak için genellikle indirgen ajanlar liç esnasında kullanılmaktadır. Bu çalışmada indirgen ajan olarak Malatya Şeker Fabrikasından temin edilen melas kullanılmıştır.

Atık bir pil tozu asidik bir çözeltide çözündürüldüğü zaman hem çinko hem de mangan oksitler çözünerek $\mathrm{Zn}^{2+}$ ve $\mathrm{Mn}^{2+}$ formunda çözelti ortamına geçerler. Çözeltiye geçen iyonları birbirinden ayırarak kazanmak için çöktürme, solvent ekstraksiyonu, adsorpsiyon ve iyon değişimi gibi ayırma yöntemlerinin uygulanması gerekir. $\mathrm{Bu}$ işlemler belli bir maliyete sahiptir ve proses ekonomisini olumsuz yönde etkileyebilir. Yukarıda ifade edildiği gibi çinkonun amfoter özelliğinden yararlanarak atık pil tozu önce bazik bir çözeltide liç işlemine tabi tutularak çinko oksidin seçimli olarak çözünmesi sağlanabilir. Daha sonra kalan katı kalıntıya indirgen bir madde varlığında asidik bir çözeltide ikinci bir liç işlemi uygulanarak mangan iyonları çözeltiye alınabilir. Böylece çinko ve mangan iyonlarını bir arada içermeyen ve ilgili iyon bakımından zengin iki farklı liç çözeltisi elde edilebilir. Bu işlemler sonucunda elde edilen çözeltilerden mangan ve çinko iyonları çeşitli bileşikleri halinde kazanılabilir. Önceki çalışmamızda yukarıda sözü edilen iki kademeli liç yöntemi atık alkali pil tozlarına uygulanmış ve çinko ve mangan iyonlarını ayrı ayrı içeren liç çözeltileri elde edilmiştir [29]. Bu çözeltilerden çinko ve mangan iyonları karbonat halinde çöktürülmüş ve kalsinasyon işlemi uygulanarak oldukça saf halde $\mathrm{ZnO}$ ve $\mathrm{MnO}$ bileşikleri elde edilmiştir.

Mevcut çalışmada, hem bitmiş çinko karbon hem de alkali çinko mangan dioksit pillerden hazırlanmış olan atık pil tozları kullanılarak, pil tozundaki mangan oksitlerin çözünürlüğünün optimizasyonu incelenmiştir. Bu çalışmada da her iki metal türünü birlikte içermeyen bir çözelti elde edilmesi hedeflendiği için ilk olarak pil tozundaki çinko oksit kısmı nitrik asit çözeltilerinde kısa bir süre için çözündürülmüştür. Nitrik asit kuvvetli bir asit olmakla birlikte yükseltgen bir özellik gösterir. Dolayısıyla pil tozundaki çinko oksit Eşitlik 2'de verilmiş olan reaksiyona göre çözünerek $\mathrm{Zn}^{2+}$ halinde çözeltiye geçerken, mangan oksitler nitrik asidin bu yükseltgen etkisi sebebiyle kısmen çözünebilmektedir.

$\mathrm{ZnO}+2 \mathrm{HNO}_{3} \rightarrow \mathrm{Zn}^{2+}+2 \mathrm{NO}_{3}^{-}+\mathrm{H}_{2} \mathrm{O}$

Deneyler esnasında 10 dakikalık reaksiyon süresi sonunda çinko oksidin tamamen çözündüğü ve mangan oksitlerin ise ancak \%7 civarında çözünebildiği tespit edilmiştir. Dolayısıyla özellikle reaksiyon süresi, sülfürik asit derişimi ve reaksiyon sıcaklığının ayarlanması suretiyle pil tozundan çözünecek mangan miktarı minimum düzeyde tutulabilir. Böylece elde edilecek çözeltideki çinko kazanılmak istendiğinde, çözeltiye geçmiş olan az miktardaki mangan iyonlarını uzaklaştırmak nispeten daha kolay ve daha az masraflı olacaktır.

Çinkonun çözünmesinden sonra elde edilen katı kalıntıdaki manganı kazanmak için kolay temin edilebilirliği, ucuz olması ve çoğu liç işlemlerinde 
etkili bir çözücü olması sebebiyle liç reaktifi olarak sülfürik asit kullanılmıştır. Kalıntıda bulunabilecek mangan oksitlerin sülfürik asit çözeltilerinde çözünme reaksiyonları Eşitlik 3-6’da verildiği gibi yazılabilir [30].

$$
\begin{aligned}
& \mathrm{MnO}_{2}+\mathrm{H}_{2} \mathrm{SO}_{4} \rightarrow \mathrm{MnSO}_{4}+\mathrm{H}_{2} \mathrm{O}+1 / 2 \mathrm{O}_{2} \\
& \mathrm{Mn}_{2} \mathrm{O}_{3}+\mathrm{H}_{2} \mathrm{SO}_{4} \rightarrow \mathrm{MnSO}_{4}+\mathrm{MnO}_{2}+\mathrm{H}_{2} \mathrm{O} \\
& \mathrm{Mn}_{3} \mathrm{O}_{4}+2 \mathrm{H}_{2} \mathrm{SO}_{4} \rightarrow 2 \mathrm{MnSO}_{4}+\mathrm{MnO}_{2}+2 \mathrm{H}_{2} \mathrm{O}(5) \\
& \mathrm{MnO}+\mathrm{H}_{2} \mathrm{SO}_{4} \rightarrow \mathrm{MnSO}_{4}+\mathrm{H}_{2} \mathrm{O}
\end{aligned}
$$

Ancak bu reaksiyonlarda görüldüğü gibi $\mathrm{MnO}_{2}$, $\mathrm{Mn}_{2} \mathrm{O}_{3}$ ve $\mathrm{Mn}_{3} \mathrm{O}_{4}$ gibi mangan oksitler tamamiyla $\mathrm{Mn}^{2+}$ iyonu haline indirgenememektedir. $\mathrm{Bu}$ sebeple indirgeyici bir özelliğe sahip olan melas liç çözeltisine ilave edilerek sözü edilen mangan oksitlerin çözünürlügü arttırılabilir.

Melas, şeker üretimi sonucunda ortaya çıkan ve yaklaşık \%50 civarında kristallenemeyen şeker içeren kahve renkli oldukça viskoz sıvı bir maddedir. Başlıca glikoz, früktoz ve sükroz içeren melas, hayvan yemlerinde katk1 maddesi olarak, fermantasyonla etil alkol üretiminde ve sıvı şeker üretiminde kullanılmaktadır. Melasın bünyesinde bulunan ve kimyasal formülleri $\mathrm{C}_{6} \mathrm{H}_{12} \mathrm{O}_{6}$ olan glikoz ve früktoz indirgen şeker olarak bilinir [31,32]. Mangan oksitlerin indirgenme siras1 Eşitlik 7'de verildiği gibi yazılabilir [33].

$\mathrm{MnO}_{2} \rightarrow \mathrm{Mn}_{2} \mathrm{O}_{3} \rightarrow \mathrm{Mn}_{3} \mathrm{O}_{4} \rightarrow \mathrm{MnO}$

Böylece melas içeren sülfürik asit çözeltilerinde esas olarak $\mathrm{MnO}_{2}$ için çözünme reaksiyonunun Eşitlik 8'deki gibi olduğu söylenebilir.

$12 \mathrm{MnO}_{2}+\mathrm{C}_{6} \mathrm{H}_{12} \mathrm{O}_{6}+24 \mathrm{H}^{+} \rightarrow$

$12 \mathrm{Mn}^{2+}+6 \mathrm{CO}_{2}+18 \mathrm{H}_{2} \mathrm{O}$

Bu reaksiyon neticesinde (2+)'dan daha yüksek yükseltgenme basamağına sahip mangan türleri sulu ortamda çözünürlüğü oldukça fazla olan $\mathrm{Mn}^{2+}$ iyonuna kadar indirgenmiş olur. Böylece indirgen bir madde varlığında gerçekleştirilen liç işlemiyle katı fazdaki manganın daha fazla çözünmesi sağlanmış olur ve yüksek mangan çözünme verimine ulaşılabilir.
Deney tasarımında yanıt yüzey yöntemi (RSM) yanıt veya bağımlı değişken üzerine bağımsız değişkenlerin etkilerini belirlemek ve optimum yanıtı elde etmek için kullanılır. RSM'nin en çok kullanılan yöntemlerinden biri olan merkezi karma tasarım (CCD) olup faktörlerin düzeylerini belirlemek ve yanıt tahmini için ikinci derece bir polinom modeli elde etmek için kullanılır. Bununla birlikte üç farklı CCD yöntemi bulunmakta olup bunlardan birisi olan yüzey merkezli kompozit tasarım (CCF) yöntemi bu çalışmada uygulanmıştır. Toplam deney sayısı $2^{\mathrm{n}}$ faktöriyel düzeninde $2^{\mathrm{n}}+2 \mathrm{n}+\mathrm{n}_{0}$ olarak hesaplanmıştır. Burada $\mathrm{n}$ bağımsız değişken sayısını ve $\mathrm{n}_{0}$ ise merkezi noktayı temsil etmektedir. Çalışmada 3 farklı bağımsız değişken seçildiğinden, $2^{3}=8$ faktöriyel nokta ve 2 x3=6 eksenel nokta bulunmaktadır. Merkezi noktada yapılacak tekrar deney sayıs 6 olarak seçilmiş olup toplam deney sayısı 20 olarak belirlenmiştir. Oluşturulan deney planı ve bu deneylerden elde edilen sonuçlar Çizelge 2'de gösterilmiştir.

Çizelge 2. CCF yöntemine göre belirlenen deney planı ve elde edilen yanıtlar

\begin{tabular}{|c|c|c|c|c|}
\hline Deney & $\begin{array}{c}\text { Sülfürik asit } \\
\text { derişimi } \\
(\mathrm{A}), \text { mol/L }\end{array}$ & $\begin{array}{c}\text { Reaksiyon } \\
\text { sicaklığı } \\
(\mathrm{B}),{ }^{\circ} \mathrm{C}\end{array}$ & $\begin{array}{c}\text { Reaksiyon } \\
\text { süresi } \\
\text { (C), dk }\end{array}$ & $\begin{array}{c}\text { \%Çözünen } \\
\text { mangan, Y }\end{array}$ \\
\hline 1 & 0,5 & 30 & 10 & 8,0 \\
\hline 2 & 2,5 & 30 & 10 & 17,2 \\
\hline 3 & 0,5 & 70 & 10 & 26,6 \\
\hline 4 & 2,5 & 70 & 10 & 34,7 \\
\hline 5 & 0,5 & 30 & 120 & 23,4 \\
\hline 6 & 2,5 & 30 & 120 & 44,7 \\
\hline 7 & 0,5 & 70 & 120 & 84,0 \\
\hline 8 & 2,5 & 70 & 120 & 92,6 \\
\hline 9 & 0,5 & 50 & 65 & 31,0 \\
\hline 10 & 2,5 & 50 & 65 & 44,3 \\
\hline 11 & 1,5 & 30 & 65 & 27,5 \\
\hline 12 & 1,5 & 70 & 65 & 71,0 \\
\hline 13 & 1,5 & 50 & 10 & 17,0 \\
\hline 14 & 1,5 & 50 & 120 & 56,0 \\
\hline 15 & 1,5 & 50 & 65 & 39,7 \\
\hline 16 & 1,5 & 50 & 65 & 40,7 \\
\hline 17 & 1,5 & 50 & 65 & 39,7 \\
\hline 18 & 1,5 & 50 & 65 & 39,7 \\
\hline 19 & 1,5 & 50 & 65 & 39,7 \\
\hline 20 & 1,5 & 50 & 65 & 40,7 \\
\hline
\end{tabular}


Değişkenler arasındaki ilişkiyi temsil edecek modeli belirlemek için deney sonuçlarına çoklu regresyon analizi uygulanmıştır. Bazı parametre etkileri göz önüne alınarak elde edilen model modifiye edilmiş ve sonuç olarak yanıt ile bağımsız değişkenler arasındaki ilişkiyi gösteren kodlanmış modifiye model denklemi Eşitlik 9'da verilmiştir.

$\mathrm{Y}=40,29+6,05 \mathrm{~A}+21,70 \mathrm{~B}+19,72 \mathrm{C}-$

$1,72 \mathrm{AB}+1,58 \mathrm{AC}+9,05 \mathrm{BC}-3,03 \mathrm{~A}^{2}+8,52 \mathrm{~B}^{2}-4,28 \mathrm{C}^{2}-$

$1,45 \mathrm{ABC}-3,63 \mathrm{~A}^{2} \mathrm{~B}$

Eşitlik 9'daki modelin istatistiksel önemi ve uygunluğu varyans analizi ve F-testi yapılarak belirlenebilir. Böylece, elde edilen deney yanıtları için varyans analiz sonuçları belirlenmiş ve bu sonuçlar F testine göre yorumlanmıştır. Varyans analizi sonuçları Çizelge 3 'te gösterilmiştir. $\mathrm{Bu}$ analiz sonucunda elde edilen ve Çizelge 3'te verilmiş olan Prob $>\mathrm{F}$ değerleri incelenen parametrelerin önemi ve birbirleri ile olan etkileşimi hakkında fikir verir. Başka bir ifadeyle varyans analizi sonucunda elde edilen bilgilerden birisi olan Prob $>F$ değerleri dikkate alınarak deneysel parametrelerden hangisinin yanıt üzerinde daha etkili olduğu tespit edilebilir.

Prob $>$ F değeri 0,05 anlamlılık düzeyinden küçük olan deney parametrelerinin, elde edilen yanit üzerinde daha etkili olduğu ifade edilebilir. Çizelge 3'ten her üç parametre için Prob $>F$ değerlerinin 0,05 'den daha küçük olduğu gözlenmektedir. Dolayısıyla sülfürik asit derişimi, reaksiyon sicaklığı ve reaksiyon süresinin mangan çözünürlüğü üzerinde önemli bir etkiye sahip olduğu söylenebilir. Aynı zamanda bağımsız değişkenler ile yanıt arasında ikinci ve üçüncü dereceden bir ilişki olduğu ve yanıt üzerinde etkili olduğu da Çizelge 3’ten görülmektedir.

Çizelge 3. Varyans analiz (ANOVA) sonuçları

\begin{tabular}{|c|c|c|c|c|c|c|c|}
\hline Değişimin Kaynağ 1 & Katsayılar & $\begin{array}{c}\text { Kareler } \\
\text { Toplamı }\end{array}$ & $\begin{array}{c}\text { Serbestlik } \\
\text { Derecesi }\end{array}$ & $\begin{array}{c}\text { Kareler } \\
\text { Ortalaması }\end{array}$ & F-Değeri & Prob.>F & Sonuç \\
\hline $\mathrm{A}_{0}$ & $+40,29$ & 8730,45 & 11 & 793,68 & 1696,76 & $<0,0001$ & Önemli \\
\hline $\mathrm{A}$ & $+6,05$ & 366,02 & 1 & 366,02 & 782,50 & $<0,0001$ & Önemli \\
\hline $\mathrm{B}$ & $+21,70$ & 941,78 & 1 & 941,78 & 2013,38 & $<0,0001$ & Önemli \\
\hline $\mathrm{C}$ & $+19,72$ & 3888,78 & 1 & 3888,78 & 8313,61 & $<0,0001$ & Önemli \\
\hline $\mathrm{AB}$ & $-1,72$ & 23,81 & 1 & 23,81 & 50,89 & $<0,0001$ & Önemli \\
\hline $\mathrm{AC}$ & $+1,58$ & 19,85 & 1 & 19,85 & 42,43 & 0,0002 & Önemli \\
\hline $\mathrm{BC}$ & $+9,05$ & 655,22 & 1 & 655,22 & 1400,76 & $<0,0001$ & Önemli \\
\hline $\mathrm{A}^{2}$ & $-3,03$ & 25,28 & 1 & 25,28 & 54,04 & $<0,0001$ & Önemli \\
\hline $\mathrm{B}^{2}$ & $+8,52$ & 199,54 & 1 & 199,54 & 426,58 & $<0,0001$ & Önemli \\
\hline $\mathrm{C}^{2}$ & $-4,28$ & 50,42 & 1 & 50,42 & 107,79 & $<0,0001$ & Önemli \\
\hline ABC & $-1,45$ & 16,82 & 1 & 16,82 & 35,96 & 0,0003 & Önemli \\
\hline $\mathrm{A}^{2} \mathrm{~B}$ & $-3,63$ & 21,02 & 1 & 21,02 & 44,95 & 0,0002 & Önemli \\
\hline Kalan & & 3,74 & 8 & 0,47 & & & \\
\hline Açıklanamayan & & 2,41 & 3 & 0,80 & 3,01 & & \\
\hline k1sim & & 1,33 & 5 & 0,27 & & & \\
\hline Hata & & 8734,19 & 19 & & & & \\
\hline Toplam & & & & & & \\
\hline
\end{tabular}

İstatiksel model için $\mathrm{R}^{2}$ ve $\mathrm{R}^{2}$ adj değerleri her ikisi içinde 0,999 olarak belirlenmiştir. $\mathrm{Bu}$ değerlerin yüksek olması çalışmada seçilen modifiye modelin uygun olduğunu göstermektedir. Deneysel olarak 
elde edilen yanıt değerleri ile model denkleminden hesaplanan değerler arasındaki uyumu görmek için deneysel yanıtlara karşı tahmin edilen yanıtların grafiği Şekil 3'te verilmiştir. Bu şekilden tahmin edilen değerler ile deneysel değerler arasındaki uyumun oldukça iyi olduğu gözlenmektedir.

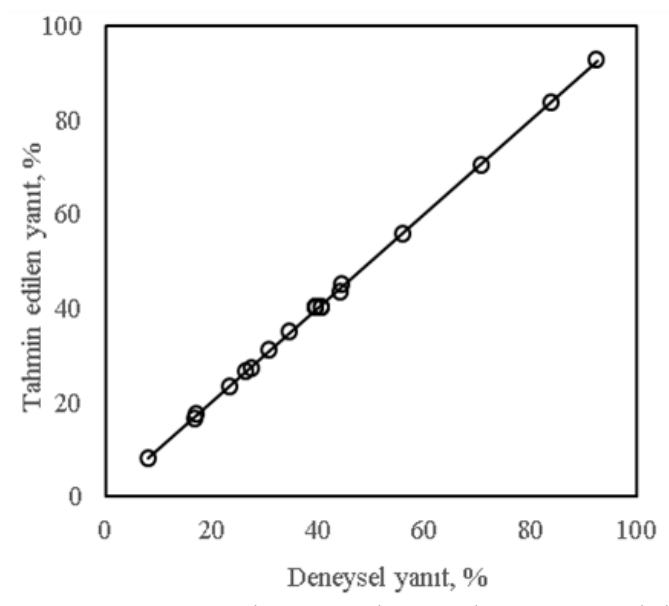

Şekil 3. Deneysel yanıtlara karşı modelden hesaplanan yanıtların karşılaştırılması

Modelin uygunluğu belirlendikten sonra nümerik optimizasyon yöntemi kullanılarak optimum deney koşullarının belirlenmesine yönelik çalışmalar yapılmıştır. Model denkleminden elde edilen üç boyutlu yanıt yüzey grafikleri her bir değişkenin düzeyi ile yanıtlar arasındaki ilişkiyi gösterir ve değişkenlerden biri merkez düzeyinde sabit tutulurken diğer iki değişkenin hem birbirleri ile olan etkileşimini hem de yanıt üzerindeki etkisini görmek için kullanılabilir.

Mangan çözünürlüğü üzerine sülfürik asit derişimi ve reaksiyon süresinin etkisi Şekil 4'de gösterilmiştir. $\mathrm{Bu}$ şekil sülfürik asit derişimi ve reaksiyon süresi düşük seviyelerde iken mangan çözünme veriminin de düşük seviyelerde olduğunu, sülfürik asit derişimi ve reaksiyon süresi arttığı zaman çözünürlüğün de arttığını göstermektedir.

Gerek Şekil 4 gerekse Çizelge 2'den görüleceği gibi sülfürik asit derişimi ve reaksiyon süresinin artmasıyla mangan çözünürlüğü de artmaktadır. Ancak sülfürik asit derişiminin reaksiyon süresinden daha etkili bir parametre olduğu da anlaşılmaktadır.

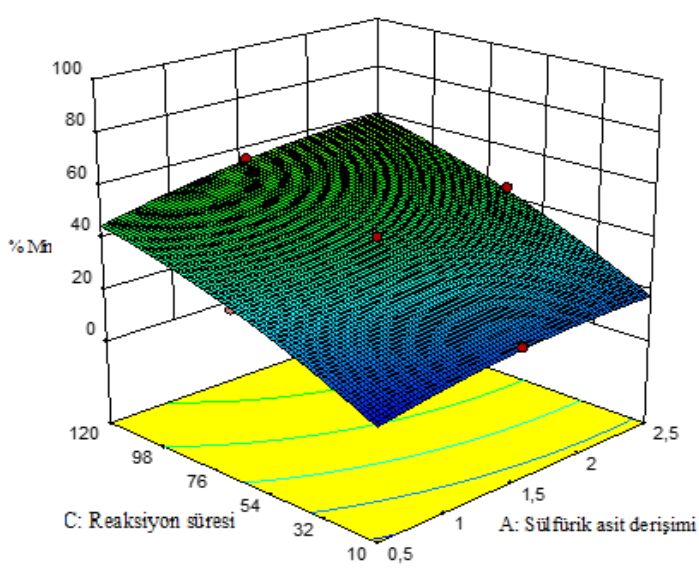

Şekil 4. Mangan çözünürlüğüne sülfürik asit derişimi ve reaksiyon süresinin etkisi

Manganın liç verimine sülfürik asit derişimi ve reaksiyon sıcaklığının etkisini gösteren üç boyutlu grafik Şekil 5'te verilmiştir. Bu şekil sülfürik asit derişimi ve reaksiyon sıcaklığg değerleri düşük seviyelerde olduğunda yanıtın da düşük olduğunu, ancak sülfürik asit derişimi ve reaksiyon sıcaklığı arttığı zaman liç verimin de önemli ölçüde arttığını göstermektedir. Çizelge 2'deki veriler de incelendiği zaman sülfürik asit derişiminin ve reaksiyon sıcaklığının artmasıyla çözünmenin arttığ1 görülebilir.

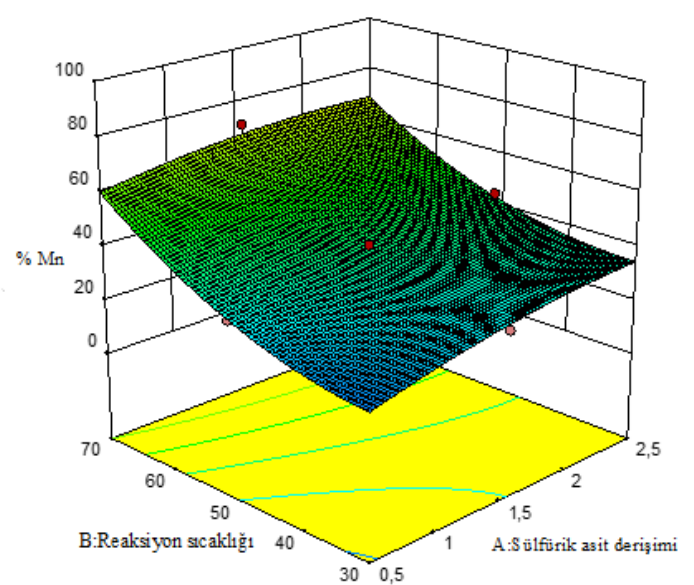

Şekil 5. Mangan çözünürlüğüne sülfürik asit derişimi ve reaksiyon sıcaklığının etkisi 
Sabit reaksiyon süreleri dikkate alınarak sülfürik asit derişimi ve reaksiyon sıcaklı̆̆ı mukayese edildiği zaman, reaksiyon sıcaklığının artmasının mangan liç verimi üzerinde sülfürik asit derişiminden daha etkili bir parametre olduğu anlaşılmaktadır.

Şekil 6'da manganın çözünürlüğüne reaksiyon sıcaklığının ve reaksiyon süresinin birlikte etkisini gösteren üç boyutlu yanıt yüzey grafiği çizilmiştir. Şekil 6 reaksiyon sıcaklığı ve reaksiyon süresi düşük iken çözünmenin de düşük seviyelerde kaldığını ancak bu iki parametrenin değerinin artmasının çözünme verimini de artırdığını göstermektedir. Çizelge 2'deki deneysel yanıt değerleri de incelendiği zamanda sülfürik asit derişimi sabit olduğunda reaksiyon sıcaklığı ve reaksiyon sürenin artmasiyla mangan çözünürlüğünün arttığı görülmektedir. Ancak bu artışta reaksiyon sıcaklığının rolünün daha önemli olduğu anlaşılmaktadır.

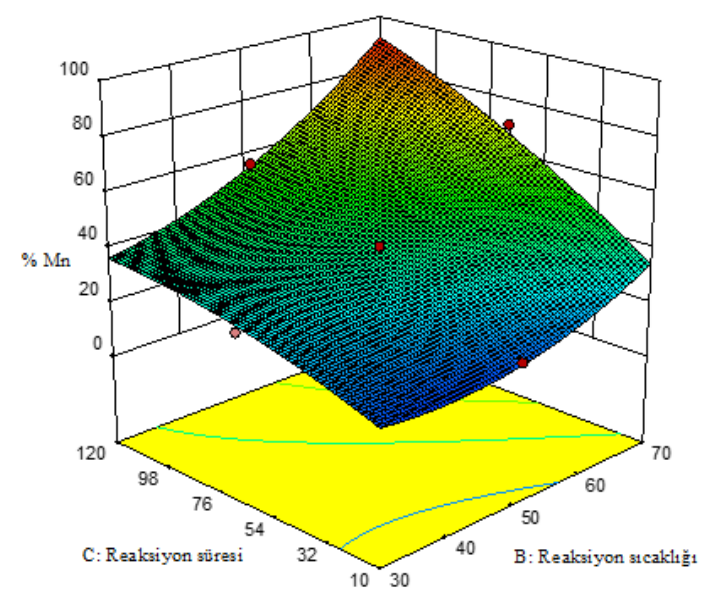

Şekil 6. Mangan çözünürlüğüne reaksiyon sıcaklığı ve reaksiyon süresinin etkisi

Kullanılan materyalin bileşimi, kullanılan parametreler ve değerleri ile uygulanan deneysel yöntem farklılık gösterse de mevcut çalışmadan elde edilen bulguların literatürdeki benzer çalışmalarla uyumlu olduğu gözlenmiştir. İndirgen madde olarak glikoz varlığında sülfürik asit çözeltilerinde atık pil tozlarının çözünmesi için gerçekleştirilen çalışmada optimum sülfürik asit derişimi $2 \mathrm{~mol} / \mathrm{L}$ ve reaksiyon sıcaklığ $100{ }^{\circ} \mathrm{C}$ olarak belirlenmiş ve bu şartlarda mangan çözünürlüğünün \%100'e yakın olduğu belirtilmiştir [6]. Farklı türde atık pillerden elde edilmiş olan pil tozlarından metal kazanılması amacıyla yapılan bir çalışmada sülfürik asidin daha etkili bir çözücü olduğu ve $1 \mathrm{~mol} / \mathrm{L}$ sülfürik asit derişiminin en uygun değer olarak belirlendiği ifade edilmiştir. Ancak indirgeyici bir maddenin kullanılmadığı çalışmada mangan için yaklaşık \%30 bir liç verimine ulaşıldı̆̆ belirlenmiştir [20]. Yine farklı türde atık pillerden hazırlanan pil tozundaki metallerin çözünürlüğünün incelendiği bir çalışmada sülfürik asit derişimi için 1,34 mol/L değeri optimum değer olarak belirlenmiş ve mangan liç veriminin \%94 olduğu tespit edilmiştir [24]. Sülfürik asit derişimi ve reaksiyon sıcaklığ için optimum değerlerin $1 \mathrm{~mol} / \mathrm{L}$ ve $70{ }^{\circ} \mathrm{C}$ olarak belirlendiği başka bir çalışmada ise mangan liç verimi \%15 olarak belirlenmiştir. Ancak bu çalışmada da herhangi bir indirgeyici madde kullanılmamış ve esas olarak pil tozundaki çinkonun seçimli çözündürülmesi hedeflendiği için mangan liç veriminin düşük seviyelerde kaldığ 1 ifade edilmiştir [25].

Katı/sıv1 oranının 8/500 g/mL, karıştırma hızının $500 \mathrm{rpm}$ ve melas miktarının $3 \mathrm{~g}$ olarak sabit alındığı mevcut çalışmada, sülfürik asit derişimi için $2,07 \mathrm{~mol} / \mathrm{L}$, reaksiyon sıcaklığ 1 için $68,8^{\circ} \mathrm{C}$ ve reaksiyon süresi için $120 \mathrm{dk}$ optimum deney koşulları olarak belirlenmiş ve bu koşullarda pil tozundaki manganın \%93'ünün katı fazdan çözelti ortamına alındığı tespit edilmiştir. Esas olarak liç çalışmalarında kullanılan çözücünün derişimi, reaksiyon sicaklığ 1 , tane boyutu, katı/sıv1 oran1, karıştırma hızı ve reaksiyon süresi gibi parametreler liç verimi ve proses ekonomisi üzerinde etkilidir. Yukarıda da ifade edildiği gibi deneysel çalışmalarda kullanılan materyalin bileşimi, seçilen bağımsız değişkenler ve bunların değerleri ile uygulanan deneysel yönteme bağlı olarak elde edilen sonuçlar farklılık gösterse de genel olarak mevcut çalışmadan elde edilen bulgular ile literatürdeki çalışmalardan elde edilen bulgular arasında bir uyum olduğu ifade edilebilir. Bizim çalışmamızın en önemli dezavantajının literatürdeki çalışmalardan daha düşük katı/sıv1 oranlarında çalışılmış olduğu söylenebilir. Literatürdeki çalışmalarda genellikle okzalik asit, 
sitrik asit, glikoz, hidrojen peroksit ve askorbik asit gibi meddeler mangan çözünürlüğünü arttırmak amacıyla indirgeyici madde olarak kullanılmıştır. $\mathrm{Bu}$ kimyasalların bir maliyetinin olması prosesin ekonomisini olumsuz yönde etkileyebilir. Bizim çalışmamızda ise indirgeyici madde olarak bir endüstriyel atık olan melas kullanılmıştır. Dolayısyla bu çalışmada daha düşük maliyetli bir indirgeyici maddenin kullanılmış olması çalışmanın en önemli avantajı olduğu söylenebilir.

\section{SONUÇLAR}

Bu çalışmada, atık çinko karbon ve alkali pillerden elde edilen pil tozundaki çinko oksit giderildikten sonra elde edilen katı kalıntıdaki manganın, indirgen madde olarak melas içeren sülfürik asit çözeltilerindeki çözünürlüğü için optimum koşulların belirlenmesi incelenmiştir. Sülfürik asit derişimi, reaksiyon sicaklığı ve reaksiyon süresi bağımsız değişkenler olarak seçilmiş ve mangan çözünürlügü üzerine olan etkileri belirlenmiştir. Bağımsız değişkenler ve yanıt arasındaki ilişkiyi gösteren modifiye bir model denklemi önerilmiştir. Elde edilen sonuçlara göre her üç parametrenin değerinde meydana gelen bir artışın manganın çözünmesini olumlu yönde etkilediği belirlenmiștir. Sülfürik asit derişimi çözünme üzerinde önemli bir parametre olsa da reaksiyon sıcaklığı ve reaksiyon süresinin derişimden daha etkili parametreler olduğu belirlenmiştir. Optimum deney koşulları belirlenmiş ve sülfürik asit derişiminin 2,07 $\mathrm{mol} / \mathrm{L}$, reaksiyon sıcaklığının $68,8{ }^{\circ} \mathrm{C}$ ve reaksiyon sürenin $120 \mathrm{dk}$ olduğu şartlarda manganın liç veriminin yaklaşık olarak \%93 olduğu tespit edilmiştir.

\section{TEŞEKKÜR}

Bu çalışma İnönü Üniversitesi Bilimsel Araştırma Projeleri Koordinasyon Birimi tarafindan desteklenmiştir (Proje numarası: FDK-2018-970).

\section{KAYNAKLAR}

1. Veloso, L.R.S., Rodrigues, L.E.O.C., Ferreira, D.A, Magalhaes F.S., Mansur, M.B., 2005. Development of a Hydrometallurgical Route for the Recovery of Zinc and Manganese from Spent Alkaline Batteries, J. Power Sources, 152, 295-302.

2. Bernades, A.M., Espinosa, D.C.R., Tenorio, J.A.S., 2004. Recycling of Batteries: A Review of Current Processes and Technologies, J. Power Sources, 130, 291-298.

3. Xionga, S., Lia, X., Liua, P., Haoa, S., Haoa, F., Yinb, Z., Liua, J., 2018. Recovery of Manganese from Low Grade Pyrolusite Ore by Reductively Acid Leaching Process Using Lignin as a Low Cost Reductant, Miner. Eng., 125, 126-132.

4. Yamaguchi, T., Nagano, H., Murai, R., Sugimori, H., Sekiguchi, C., Sumi, I., 2018. Development of Mn Recovery Process from Waste Dry Cell Batteries, J. Mater. Cycles Waste Manag., 20, 1909-1917.

5. Salgado, A.L., Veloso, A.M.O, Pereira, D.D., Gontijo, G.S., Salum, A., Mansur, M.B., 2003. Recovery of Zinc and Manganese from Spent Alkaline Batteries by Liquid-Liquid Extraction with Cyanex 272, J. Power Sources, 115, 367-373.

6. Biswas, R.K., Karmakar, A.K., Kumar, S.L., 2016. Recovery of Maganese and Zinc from Spent Zn-C Cell Powder: Experimental Design of Leaching by Sulfuric Acid Solutions Containing Glucose, Waste Manage., 51, 174-183.

7. De Souza, C.C.B.M., De Oliveria, D.C., Tenorio, J.A.S., 2001. Characterization of Used Alkaline Batteries Powder and Analysis of Zinc Recovery by Acid Leaching, J. Power Sources, 103, 120-126.

8. Ferella, F., Michelis, I.D., Pagnanelli, F., Beolchini, F., Furlani, G., Navarra, M., Veglio, F., Toro, L., 2006. Recovery of Zinc and Manganese from Spent Batteries by Different Leaching Systems, Acta Metall. Slovaca, 12, 95-104.

9. Gega, J., Walkowiak, W., 2011. Leaching of Zinc and Manganese from Used up ZincCarbon Batteries Using Aqueous Sulfuric Acid Solution, Physicochem. Prob. Miner. Process., 46, 155-162.

10. Turhan Özdemir, G.D., Demirkıran, N., 2016. Atık Alkali Pillerden Elde Edilen Çinko Tozun Sodyum Hidroksit Çözeltilerindeki 
Çözünürlüğünün İncelenmesi, AKU J. Sci. Eng., 16, 61-67.

11. Demirkıran, N., Turhan Özdemir, G.D., 2019. A Kinetic Model for Dissolution of Zinc Oxide Powder Obtained from Waste Alkaline Batteries in Sodium Hydroxide Solutions, Metall. Mater. Trans. B, 50B, 491-501.

12. Baba, A.A., Adekola, A.F., Bale, R.B., 2009. Development of a Combined Pyro-and HydroMetallurgical Route to Treat Spent ZincCarbon Batteries, J. Hazard. Mater., 171, 838-844.

13. Senanayake, G., Shin, S.M., Senaputra, A., Winn, A., Pugaev, D., Avraamides, J., Sohn, J.S., Kim, D.J., 2010. Comparative Leaching of Spent Zinc-Manganese-Carbon Batteries Using Sulfur Dioxide in Ammoniacal and Sulfuric Acid Solution, Hydrometallurgy, 105, 36-41.

14. Shin, S.M., Senanayake, G., Sohn, J., Kang, J., Yang, D., Kim, T., 2009. Separation of Zinc from Spent Zinc-Carbon Batteries by Selective Leaching with Sodium Hydroxide, Hydrometallurgy, 96, 349-353.

15. Demirkıran, N., 2015. Examination of the Use of Ammonium Acetate as Lixiviant in Recovery of Zinc from Waste Batteries and Kinetic Analysis, Environ. Eng. Manag J., 14, 51-56.

16. Karakaya, E., Kükrer, T., Veglio, F., Akçıl, A.U., Kitis, M., 2007. Atık Alkali ve ÇinkoKarbon Pillerden Mangan ve Çinko Geri Kazanımı: İnorganik ve Organik Asitlerle Liç Testleri, 7. Ulusal Çevre Mühendisliği Kongresi, İzmir, Turkiye, 24-27 Ekim, 301-305.

17. Sayılgan, E., Kükrer, T., Yigit, N.O., Civelekoglu, G., Kitis, M., 2010. Acidic Leaching and Precipitation of Zinc and Manganese from Spent Battery Powder Using Various Reductants, J. Hazard. Mater., 173, 137-143.

18. Bezerra, M.A., Santelli, R.E., Oliveira, E.P., Villar, L.S., Escaleira, L.A., 2008. Response Surface Methodology (RSM) as a Tool for Optimization in Analytical Chemistry, Talanta, 76, 965-977.

19. Azizi, D., Shafaei, S.Z., Noaparast, M., Abdollahi, H., 2012. Modeling and Optimization of Low-grade Mn Bearing Ore
Leaching Using Response Surface Methodology and Central Composite Rotatable Design, Trans. Nonferr. Met. Soc. China, 22, 2295-2305.

20. Tanong, K., Coudert, L., Blais, J.F., 2016. Recovery of Metals from a Mixture of Various Spent Batteries by a Hydrometallurgical Process, J. Environ. Manag., 181, 95-107.

21. Turan M.D., Altundoğan H.S., 2011. Hidrometalurjik Araştırmalarda Yanıt Yüzey Yöntemlerinin (YYY) Kullanımı, Madencilik, 50, 11-23.

22. Montgomery, D.C., 2001. Design and Analysis of Experiments, $5^{\text {th }}$ Edition, Wiley, New York.

23. Ijadi Bajestani, M., Mousavi, S.M., Shojaosadati, S.A., 2014. Bioleaching of Heavy Metals from Spent Household Batteries using Acidithiobacillus Ferrooxidans: Statistical Evaluation and Optimization, Sep. Purif. Technol., 136, 309-316.

24. Tanong, K., Coudert, L., Chartier, M., Mercier, G., Blais, J.F., 2017. Study of the Factors Influencing the Metals Solubilisation from a Mixture of Waste Batteries by Response Surface Methodology, Environ. Technol., 38, 3167-3179.

25. Shalchian, H., Rafsanjani-Abbasi, A., VahdatiKhaki, J., Babakhani, A., 2015. Selective Acidic Leaching of Spent Zinc-Carbon Batteries Followed by Zinc Electrowinning, Metall. Mater. Trans. B, 46B, 38-47.

26. Derikvandi, H., Nezamzadeh-Ejhieh, A., 2017. Comprehensive Study on Enhanced Photocatalytic Activity of Heterojunction ZnSNiS/Zeolite Nanoparticles: Experimental Design Based on Response Surface Methodology (RSM), Impedance Spectroscopy and GC-MASS Studies, J. Colloid Interf. Sci., 492, 652-664.

27. Yolmeh, M. Jafari, S.M., 2017. Applications of Response Surface Methodology in the Food Industry Processes, Food Bioprocess. Tech., 10, 413-433.

28. Arulkumar, M., Sathishkumar, P., Palvannan, T. 2011. Optimization of Orange G Dye Adsorption by Activated Carbon of Thespesia Populnea Pods Using Response Surface Methodology, J. Hazard. Mater., 186, 822-834. 
29. Turhan Özdemir, G.D., Demirkıran, N., 2018. Selective Dissolution of Zinc and Manganese from Waste Alkaline Battery Powders by TwoStage Leaching Method, International Conference on Innovative Engineering Applications, Sivas, Turkey, 20-22 Sept. 300-306.

30. Sadeghi, S.M., Vanpeteghem, G., Neto, I.F.F., Soares, H.M.V.M., 2017. Selective Leaching of Zn from Spent Alkaline Batteries Using Environmentally Friendly Approaches, Waste Manage., 60, 696-705.

31. Lashenn, T.A., El-Hazek, M.N., Helal, A.S., El-Nagar, W., 2009. Recovery of Manganese Using Molasses as Reductant in Nitric Acid Solution, Int. J. Miner. Process., 92, 109-114.

32. Xu, W., Liang, L., Zhu, M. 2015. Determination of Sugars in Molasses by HPLC Following Solid-Phase Extraction, Int. J. Food Prop., 18, 547-557.

33. Nayl, A.A., Ismail, I.M., Aly, H.F., 2011. Recovery of Pure $\mathrm{MnSO}_{4} \cdot \mathrm{H}_{2} \mathrm{O}$ by Reductive Leaching of Manganese from Pyrolusite Ore by Sulfuric Acid and Hydrogen Peroxide, Int. J. Miner. Process., 100, 116-123. 
